\title{
Evaluasi Stabilitas Sediaan Krim Ekstrak Etanol Daun Afrika (Vernonia amygdalina Delile) dengan Basis Vanishing Cream (VC)
}

\author{
MARIA T. NAINGGOLAN, EVA S. SIMAREMARE*, RANI D. PRATIWI \\ Program Studi Farmasi, Fakultas MIPA, Universitas Cenderawasih, Jayapura, Papua \\ Diterima: 26 Januari 2018 - Disetujui: 24 Maret 2018 \\ (C) 2018 Jurusan Biologi FMIPA Universitas Cenderawasih
}

\begin{abstract}
Daun afrika (Vernonia amygdalina) contains flavonoids, tannins, saponins, and terpenoids that can be used for pharmacology activity: annihilate the parasites that causing schistosomiasis, malaria leishmaniasis, antiamoeba, antitumor and antimicrobials. The purposes of this research were to screen the phytochemistry of african leaf, formulate and test the stability of vanishing cream (VC) base. The methods used were sample collection, extract preparation, formulation, and stability evaluation. The results showed that extract afrika leaves had alkaloids, flavonoids, tannins, saponins, steroids, and triterpenoids. Extract of daun afrika can be made to good VC base formula including organoleptic test, homogeneity test, $\mathrm{pH}$ test, spreading test, sticky test, and VC safety test by distributing questionnaires. The cream was stabil for 21 days at room temperature. Observation of physical properties good performed every week to organoleptis, $\mathrm{pH}$, adhesion, and spreading power.
\end{abstract}

Key words: stability, V. amygdalina, kill parasites, Vanishing Cream.

\section{PENDAHULUAN}

Indonesia adalah negara kepulauan yang terletak di kawasan katulistiwa. Indonesia sebagai negara mega-biodiversitas mempunyai keanekaragaman hayati yang sangat tinggi, terutama tumbuhan (Ardhita, 2013). Di antara jenis tumbuhan berbunga yang terdapat di Indonesia, 1.845 jenis diantaranya diketahui berkhasiat sebagai obat. Tumbuhan tersebut telah dipergunakan dalam pengobatan tradisional secara turun-temurun oleh berbagai etnis di Indonesia (Zuhud \& Siswoyo, 2003).

Departemen Kesehatan RI mendefenisikan tanaman obat Indonesia seperti yang tercantum dalam SK Menkes No. 149/SK/Menkes/1978, yaitu: tanaman atau bagian tanaman yang

\footnotetext{
* Alamat korespondensi:

Program Studi Farmasi, Jurusan Farmasi, FMIPA, Universitas Cendeawasih. Jl. Kamp Wolker, Kampus FMIPA Uncen Waena, Jayapura. Papua. 99351. e-mail: evasmare13@gmail.com
}

digunakan sebagai obat tradisional atau jamu, tanamana atau bagian tanaman yang digunakan sebagai bahan pemula bahan baku obat, tanaman atau tanaman yang diekstraksi dan ekstrak tanaman tersebut digunakan sebagai obat.

Salah satu bahan alam yang dapat digunakan sebagai obat yaitu tanaman daun afrika. Daun afrika dalam kehidupan sehari-hari dimakan sebagai sayuran. Tetapi daun ini mempunyai manfaat sebagai anti diabetes, antimalaria, menstabilkan tekanan darah, membantu menyembuhkan insomnia, membantu mencegah penyakit stroke, mencegah kanker, penyakit jantung, dan menghilangkan jerawat (ljeh et al., 2011).

Daun afrika (Vernonia amygdalina Delile) berasal dari suku Asteraceae banyak tumbuh di benua Afrika bagian barat terutama di Nigeria (Ibrahim et al., 2010) dan Malaysia (Atangwho et al., 2013). Daun Afrika (V. amygdalina) mengandung flavonoid, tannin, saponin, dan terpenoid (Audu et al., 2012) yang mampu membunuh 
parasit penyebab schistosomiasis, malaria leishmaniasis (Omoregie et al., 2011), antiamoeba, antitumor, antimikroba (Ijeh et al., 2011; Zenebe et al., 2015; Ibrahim \& Muhammad, 2011), antioksidan (Atangwho et al., 2013; Oriakhi et al., 2013), HIV/ AIDS (Momoh et al., 2012), antidiabetes (Akah et al., 2004; Akah et al., 2009; Modu et al., 2013). Daun minyak atsiri juga pernah didapat dari daun ini dan bersifat toksik (Asawalam \& Hassanali, 2006).

Penelitian terhadap aktivitas antimikroba ekstrak daun afrika (Afolabi et al., 2014) yang dilakukan menunjukkan hasil yang positif terhadap bakteri aktivitas Streptococcus mutans, Staphylococcus aureus dan Lactobacillu acidophilus. Ekstrak daun afrika memiliki aktivitas antibakteri yang mampu membunuh bakteri gram posirif dan gram negatif (Erasto, 2008; Bukar et al., 2013), antihelmintes (Nalule et al., 2013), antipiretik antinosiseptik (Adiukwu et al., 2013).

Penggunaan ekstrak daun Afrika secara langsung pada kulit tidak praktis, oleh karena itu perlu dibuat sediaan yang mudah digunakan seperti sediaan topikal yaitu krim. Berdasarkan latar belakang di atas, maka dibuat formula ekstrak etanol daun afrika dalam bentuk sediaan krim. Sediaan krim dipilih karena mempunyai keuntungan yaitu sederhana dalam pembuatan, mudah dalam penggunaan, daya menyerap yang baik dan memberikan rasa dingin pada kulit (BPOM, 2000).

\section{METODE PENELITIAN}

\section{Alat, Bahan, dan Sampel Penelitian}

Alat yang digunakan pada penelitian ini adalah satu set alat maserasi, neraca analitik, ayakan, oven, mortar dan stemper, wadah untuk sediaan krim, gelas kimia, cawan porselen, ayakan, $\mathrm{pH}$ meter. Bahan yang digunakan adalah Etanol 96\%, simplisia tumbuhan daun afrika, setil alkohol, metil paraben, propil paraben, gliserin, vaselin alba, dan aquadest. Bahan yang digunakan pada penelitian diperoleh dari Pemda 3 Melati kotaraja, Abepura, Jayapura.

\section{Pembuatan Simplisia}

Tumbuhan daun afrika ( $V$. amygdalina) dibersihkan dari kotoran yang melekat, dicuci dengan air, dikeringkan dengan cara dianginanginkan. Daun afrika yang sudah kering diblender hingga menjadi serbuk. Serbuk yang didapat kemudian disimpan dalam wadah bersih dan tertutup rapat.

\section{Pembuatan Ekstrak Daun Afrika}

Daun afrika ditimbang masing-masing sebanyak $1 \mathrm{~kg}$ simplisia sampel dikeringkan dengan cara diangin-anginkan. Kemudian sampel kering diblender halus. Serbuk kering yang diperoleh diayak dengan mess 60 kemudian ditimbang 50 gram. Hasil ayakan di maserasi dalam wadah kaca dengan $500 \mathrm{ml}$ etanol $96 \%$ selama 3 × 24 jam pada suhu kamar. Setelah dimaserasi, filtrat disaring menggunakan kertas saring whatmann no 1 . Hasil maserasi diuapkan dengan rotary evaporator dengan suhu $40{ }^{\circ} \mathrm{C}$ sehingga diperoleh ekstrak kental.

\section{Skrining Fitokimia}

Penapisan fitokimia dilakukan terhadap simplisia, ekstrak dan fraksi aktif meliputi

Tabel 1. Formulasi sediaan krim ekstrak daun afrika (V. amygdalina.)(Sharon et al., 2013).

\begin{tabular}{lcccc}
\hline \multicolumn{1}{c}{ Nama Bahan } & Satuan & $\mathrm{I}$ & $\mathrm{II}$ & $\mathrm{III}$ \\
\hline Ekstrak Daun Afrika & $\mathrm{g}$ & 6 & 6 & 6 \\
Setil Alkohol & $\mathrm{g}$ & 1,8 & 1 & 1,5 \\
Asam Stearat & $\mathrm{g}$ & 4 & 2 & 1,5 \\
Gliserin & $\mathrm{mL}$ & 6 & 4 & 2 \\
Vaselin Album & $\mathrm{g}$ & 6 & 2 & 1,5 \\
Metil Paraben & $\mathrm{g}$ & 0.2 & 0,2 & 0,2 \\
Propil Paraben & $\mathrm{g}$ & 0,02 & 0,02 & 0,02 \\
Propilenglikol & $\mathrm{mL}$ & 3 & 2 & 1,5 \\
Aquadest & $\mathrm{mL}$ & $\mathrm{Ad} \mathrm{100}$ & $\mathrm{Ad} \mathrm{100}$ & $\mathrm{Ad} \mathrm{100}$ \\
\hline
\end{tabular}


pemeriksaan terhadap golongan alkaloid, Fase minyak dan fase air dipanaskan hingga suhu flavonoid, saponin, kuinon, tanin dan 70-80 ${ }^{\circ} \mathrm{C}$. Setelah semuanya melebur fase air triterpenoid/steroid (Fransworth, 1966).

\section{Pembuatan Formulasi Sediaan Krim Ekstrak Daun Afrika}

Bahan-bahan fase minyak (vaselin album dan propil paraben) dan fase air (ekstrak Daun afrika, gliserin, metil paraben dan aquades) dipisahkan.

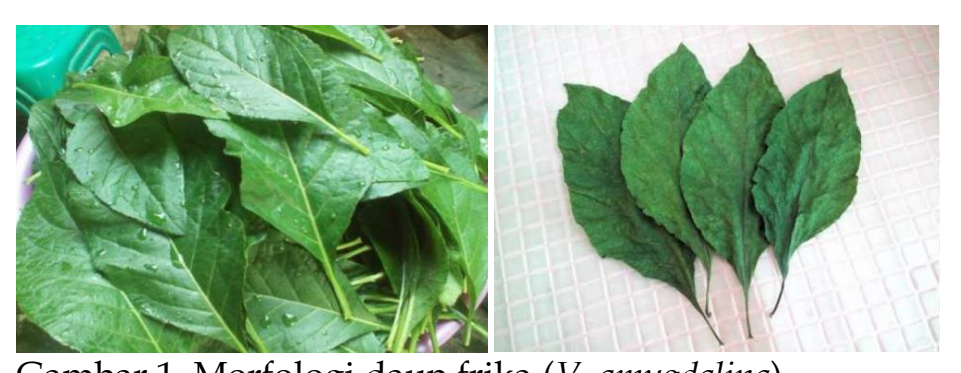

Gambar 1. Morfologi daun frika (V. amygdalina).

Tabel 2. Hasil pengamatan morfologi daun afrika ( $V$. amygdalina).

\begin{tabular}{lll}
\hline No & \multicolumn{1}{c}{$\begin{array}{c}\text { Bagian daun yang di } \\
\text { deskripsi }\end{array}$} & \multicolumn{1}{c}{ Bentuk morfologi } \\
\hline 1 & Bangun daun & Jorong, bulat panjang \\
2 & Tulang daun & Menyirip \\
3 & Ujung daun & Meruncing \\
4 & Pangkal daun & Runcing \\
5 & Tepi daun & Beringgit \\
6 & Warna daun & Hijau tua \\
7 & Warna tangkai daun & Cokelat \\
8 & Panjang tangkai daun & $2,5 \mathrm{~mm}$ \\
9 & Tangkai daun & $2-3 \mathrm{~cm}$ \\
10 & Panjang daun & $15-17 \mathrm{~cm}$ \\
11 & Lebar daun & $6-7 \mathrm{~cm}$ \\
\hline
\end{tabular}

Tabel 3. Hasil uji fitokimia pada simplisia dan ekstrak daun afrika ( $V$. amygdalina).

\begin{tabular}{lcc}
\hline Golongan senyawa & \multicolumn{2}{c}{ Hasil pengamatan } \\
\cline { 2 - 3 } & Simplisia & Ekstrak \\
\hline Alkaloid & + & + \\
Flavonoid & + & + \\
Tanin & - & + \\
Saponin & + & + \\
Kuinon & - & - \\
Steroid & - & - \\
Triterpenoid & + & + \\
\hline
\end{tabular}

Ket.: (-) tidak ada; (+) ada dimasukan sedikit ke dalam fase minyak, diaduk perlahan-lahan hingga terbentuk basis krim. Kemudian diteteskan pengaroma lalu diaduk hingga homogen dan dimasukan dalam wadah.

\section{Evaluasi Stabilitas}

Pada pengujian organoleptik dilakukan dengan mengamati sediaan dari bentuk, bau dan warna sediaan. Pada uji $\mathrm{pH}$, sebanyak 0,5 g sediaan krim ekstrak daun afrika diencerkan dengan $5 \mathrm{~mL}$ aquadest, kemudian didapat harga $\mathrm{pH}$. Pada uji Homogenitas sediaan dilakukan dengan cara mengamati hasil pengolesan krim pada plat kaca. Krim yang homogen ditandai dengan tidak terdapatnya gumpalan pada hasil pengolesan, struktur yang rata dan memiliki warna yang seragam dari titik awal pengolesan sampai titik akhir pengolesan. Krim yang diuji diambil dari empat tempat yaitu bagian atas, tengah dan bawah dari wadah krim. Pada uji daya sebar, Sebanyak 0,5 g sediaan krim diletakkan di atas kaca bulat yang berdiameter $15 \mathrm{~cm}$, kaca lainnya diletakkan diatasnya dan dibiarkan selama 1 menit. Diameter sebar diukur kemudian ditambahkan beban $100 \mathrm{~g}$, didiamkan selama 1 menit lalu diukur diameter konstannya.

Pada uji daya lekat, sediaan krim dengan berat 0,25 gram diletakkan pada gelas obyek dan ditekan dengan beban $1 \mathrm{~kg}$ selama 5 menit. Setelah itu gelas obyek dipasang pada alat tes yang diberi beban 80 gram dan kemudian dicatat waktu pelepasan krim dari gelas obyek. Pada uji stabilitas, formula yang telah dibuat kemudian dituang ke dalam wadah sebanyak $10 \mathrm{ml}$, disimpan selama 21 hari kemudian diamati pada 1 hari, 7 hari, 14 hari, dan 21 hari. Pada uji keamanan, pengujian sediaan krim yang telah dibuat dan dilakukan terhadap 26 orang sukarelawan dengan uji tempel terbuka (patchtest), dan melakukan membagi kuisioner, yakni sejumlah sediaan uji dioleskan pada tangan sukarelawan dan 
dibiarkan terbuka selama 15 menit. Kemudian dilihat reaksinya, jika tidak terjadi reaksi beri tanda $(+), \quad j k a$ terjadi reaksi (kulit merasa iritasi/gatal) beri tanda $(++)$, jika terjadi pembengkakan beri tanda (+++) (Yuniarsih, 2010).

\section{HASIL DAN PEMBAHASAN}

Pengambilan sampel segar daun afrika ( $V$. amygdalina) berasal dari Pemda 3 Melati Kotaraja, Abepura. Pengeringan sampel dilakukan dengan cara dikering-anginkan. Hasil yang diperoleh dari pengambilan sampel daun sebanyak $4,5 \mathrm{~kg}$, setelah dikeringkan berat daun sebanyak $3 \mathrm{~kg}$, dan setelah menjadi simplisia (serbuk) sebanyak $2 \mathrm{~kg}$.

\section{Ekstraksi Daun Afrika (V. amygdalina)}

Metode ekstraksi yang digunakan yaitu metode maserasi selama $3 \times 24$ jam dengan memasukan 50 gram serbuk daun afrika ( $V$. amygdalina) ke dalam $500 \mathrm{~mL}$ etanol pada bejana maserasi hingga terjadi perubahan warna hijau pekat. Ekstraksi dilakukan menggunakan pelarut etanol $96 \%$ karena etanol $96 \%$ merupakan pelarut yang aman, mudah menguap, mudah dalam menarik metabolit sekunder dari simplisia.

Ekstraksi dilakukan dengan metode maserasi karena metode ini dilakukan dengan cara perendaman dan tanpa pemanasan sehingga dapat mengurangi terurainya senyawa aktif. Hasil ekstraksi dari simplisia $50 \mathrm{~g}$ diperoleh ekstrak kental 31,72 g.

Hasil maserasi kemudian disaring dan dipekatkan dengan Rotary Evaporasi pada suhu 60 ${ }^{\circ} \mathrm{C}$ hingga pelarut terlihat sedikit dan ekstrak mulai mengental dengan tujuan untuk menghilangkan pelarut sehingga yang digunakan yaitu ekstrak kental, setelah itu diuapkan dengan hotplate hingga ekstrak yang didapatkan benarbenar kental. Warna dari ekstrak daun afrika ( $V$. amygdalina) adalah hijau tua pekat karena klorofil yang terkandung pada daun juga ikut terekstraksi.

Tabel 4. Pengamatan organoleptis VC.

\begin{tabular}{|c|c|c|c|c|}
\hline \multicolumn{5}{|c|}{ Hari Ke-1 } \\
\hline Formula & Warna & Bau & Bentuk & Tekstur \\
\hline I & Hijau Kecoklatan & Khas daun afrika & Kental & Lembut \\
\hline II & Hijau Lumut & Khas daun afrika & Kental & Lembut \\
\hline III & Hijau Lumut & Khas daun afrika & Kental & Lembut \\
\hline \multicolumn{5}{|c|}{ Hari Ke-7 } \\
\hline Formula & Warna & Bau & Bentuk & Tekstur \\
\hline I & Hijau Kecoklatan & Khas daun afrika & Kental & Lembut \\
\hline II & Hijau Lumut & Khas daun afrika & Kental & Lembut \\
\hline III & Hijau Lumut & Khas daun afrika & Kental & Lembut \\
\hline \multicolumn{5}{|c|}{ Hari Ke-14 } \\
\hline Formula & Warna & Bau & Bentuk & Tekstur \\
\hline I & Hijau Kecoklatan & Khas daun afrika & Sangat kental & Lembut \\
\hline II & Hijau Lumut & Khas daun afrika & Sangat kental & Lembut \\
\hline III & Hijau Lumut & Khas daun afrika & Sangat kental & Lembut \\
\hline \multicolumn{5}{|c|}{ Hari Ke-21 } \\
\hline Formula & Warna & Bau & Bentuk & Tekstur \\
\hline I & Hijau Kecoklatan & Khas daun afrika & Sangat Kental & Lembut \\
\hline II & Hijau Lumut & Khas daun afrika & Sangat Kental & Lembut \\
\hline III & Hijau Lumut & Khas daun afrika & Sangat Kental & Lembut \\
\hline
\end{tabular}




\section{Uji Fitokimia Daun Afrika (V. amygdalina)}

Senyawa fitokimia merupakan senyawa golongan metabolit sekunder dalam tumbuhan yang memiliki fungsi tertentu bagi manusia. Senyawa fitokimia tersebut adalah senyawa golongan alkaloid, flavonoid, tanin, kuinon, saponin, steroid dan triterpenoid. Hasil uji fitokimia baik menggunakan simplisia dan ekstrak daun afrika (Tabel 5).

Pada pengujian fitokimia digunakan simplisia. Daun afrika mengandung senyawa golongan alkaloid, flavonoid, dan saponin. Untuk pengujian fitokimia menggunakan ekstrak daun afrika mengandung alkaloid, flavonoid, tanin, saponin, steroid, dan triterpenoid.
Pada skrining alkaloid prinsipnya yaitu reaksi pengendapan yang terjadi karena adanya penggantian ligan. Atom nitrogen yang mempunyai pasangan elektron bebas pada alkaloid dapat mengganti ion iod dalam pereaksi dragendroff dan pereaksi mayer (Marliana et al., 2005). Pada pengujian ini, hasil uji Mayer menghasilkan endapan putih karena nitrogen alkaloid bereaksi dengan ion logam $\mathrm{K}+$ dari kalium tetraiodomerkurat (II) membentuk kompleks kalium-alkaloid (Marliana et al., 2005). Hasil alkaloid uji Dragendorff menghasilkan endapan jingga karena nitrogen membentuk ikatan kovalen koordinat dengan $\mathrm{K}+$ ion logam. Endapan tersebut adalah kalium-alkaloid

Tabel 5. Hasil pengujian pH VC.

\begin{tabular}{ccccc}
\hline Formula & Hari ke-1 & Hari ke-7 & Hari ke-14 & Hari ke-21 \\
\hline I & 5 & 5 & 5 & 6 \\
II & 5 & 5 & 6 & 6 \\
III & 5 & 5 & 6 & 6 \\
\hline
\end{tabular}

Tabel 6. Hasil pengujian homogenitas VC

\begin{tabular}{ccccc}
\hline Formula & Hari ke-1 & Hari ke-7 & Hari ke-14 & Hari ke-21 \\
\hline I & - & - & - & + \\
II & - & - & - & - \\
III & - & - & - & - \\
\hline
\end{tabular}

Ket.: (-) tidak terjadi perubahan, (+) terjadi perubahan.

Tabel 7. Hasil pengujian daya sebar VC.

\begin{tabular}{|c|c|c|c|c|c|c|c|c|c|}
\hline \multirow{2}{*}{$\begin{array}{c}\text { Basis } \\
\text { Formula }\end{array}$} & \multicolumn{4}{|c|}{ Daya sebar } & \multirow{2}{*}{ Formula } & \multicolumn{4}{|c|}{ Daya sebar } \\
\hline & $\begin{array}{l}\text { Hari } \\
\text { ke-1 }\end{array}$ & $\begin{array}{l}\text { Hari } \\
\text { ke-7 }\end{array}$ & $\begin{array}{l}\text { Hari } \\
\text { ke-14 }\end{array}$ & $\begin{array}{l}\text { Hari } \\
\text { ke-21 }\end{array}$ & & $\begin{array}{l}\text { Hari } \\
\text { Ke-1 }\end{array}$ & $\begin{array}{l}\text { Hari } \\
\text { ke-7 }\end{array}$ & $\begin{array}{l}\text { Hari } \\
\text { ke-14 }\end{array}$ & $\begin{array}{l}\text { Hari } \\
\text { ke-21 }\end{array}$ \\
\hline I & 3,8 & 3,5 & 4,3 & 5,0 & I & 4,0 & 5,2 & 6,7 & 7,0 \\
\hline II & 5,0 & 5,4 & 6,5 & 7,0 & II & 3,5 & 4,5 & 5,0 & 6,8 \\
\hline III & 5,3 & 6,0 & 6,6 & 7,0 & III & 5,2 & 6,5 & 6,8 & 7,0 \\
\hline
\end{tabular}

Tabel 8. Hasil pengujian daya lekat VC.

\begin{tabular}{|c|c|c|c|c|c|c|c|c|c|}
\hline \multirow{2}{*}{$\begin{array}{c}\text { Basis } \\
\text { Formula }\end{array}$} & \multicolumn{4}{|c|}{ Daya lekat (detik) } & Formula & \multicolumn{4}{|c|}{ Daya lekat (detik) } \\
\hline & $\begin{array}{l}\text { Hari } \\
\text { ke-1 }\end{array}$ & $\begin{array}{l}\text { Hari } \\
\text { ke-7 }\end{array}$ & $\begin{array}{c}\text { Hari ke- } \\
14\end{array}$ & $\begin{array}{l}\text { Hari } \\
\text { ke-21 }\end{array}$ & & $\begin{array}{l}\text { Hari } \\
\text { Ke-1 }\end{array}$ & $\begin{array}{l}\text { Hari } \\
\text { ke-7 }\end{array}$ & $\begin{array}{l}\text { Hari } \\
\text { ke-14 }\end{array}$ & $\begin{array}{l}\text { Hari } \\
\text { ke-21 }\end{array}$ \\
\hline I & 9 & 6 & 10 & 10 & I & 8 & 10 & 12 & 12 \\
\hline II & 5 & 10 & 12 & 12 & II & 8 & 9 & 10 & 12 \\
\hline III & 10 & 8 & 9 & 12 & III & 10 & 12 & 10 & 10 \\
\hline
\end{tabular}


(Marliana et al., 2005).

Pada skrining flavonoid, hasilnya uji flavonoid positif ditandai terbentuknya warna jingga, kuning atau merah yang tertarik pada lapisan amil alkohol dikarenakan terjadinya reduksi dengan $\mathrm{Mg}$ dan $\mathrm{HCl}$ pekat. Penambahan serbuk magnesium dan asam klorida pada pengujian flavonoid akan menyebabkan tereduksinya senyawa flavonoid yang ada sehingga menimbulkan reaksi warna kuning atau merah, jingga yang merupakan ciri adanya flavonoid (Robinson, 1995).

Pada skrining saponin, saponin merupakan bentuk glikosida dari sapogenin sehingga akan bersifat polar. Saponin adalah senyawa yang bersifat aktif permukaan dan dapat menimbulkan busa jika dikocok dalam air (Kristanti et al., 2008). Timbulnya busa pada uji saponin menunjukkan adanya glikosida yang mempunyai kemampuan untuk membentuk buih dalam air yang terhidrolisis menjadi glukosa dan senyawa lainnya (Marliana et al., 2005). Pada uji saponin hasilnya positif membentuk busa, setelah penambahan $\mathrm{HCl}$ $2 \mathrm{~N}$ membentuk busa yang sangat banyak. Penambahan $\mathrm{HCl} 2 \mathrm{~N}$ bertujuan untuk menambah kepolaran sehingga gugus hidrofil akan berikatan lebih stabil dan buih yang terbentuk menjadi stabil.

Pada skrining tanin, golongan tanin merupakan senyawa fenolik yang cenderung larut dalam air dan pelarut polar (Harborne, 1996). Pada uji simplisia tanin terbentuk warna hitam cokelat, sedangkan ekstrak pada pengujian polifenol/tanin terbentuk warna biru kehitaman.

Pada pengujian steroid dan triterpenoid, analisis senyawa didasarkan pada kemampuan senyawa tersebut membentuk warna dengan $\mathrm{H}_{2} \mathrm{SO}_{4}$ pekat dalam pelarut asam asetat anhidrat (Ciulei, 1984). Hasil yang diperoleh menunjukkan hasil positif dengan terbentuknya cincin berwarna kecokelatan yang menunjukkan kandungan triterpenoid dan tidak terbentuk cincin berwarna biru kehijauan sehingga negatif mengandung steroid.

\section{Formulasi Krim Daun Afrika (V. amygdalina)}

Hasil pembuatan krim tiga formulasi menunjukkan bahwa formula dapat dibuat dengan baik sehingga terbentuknya krim yang baik. Secara organoleptik penampakan hampir sama. Krim dibuat dengan metode pencampuran dua fase, yaitu fase minyak dan fase air. Kedua fase dipanaskan secara pisah dan setelah melebur keduanya dicampur menjadi satu dengan suhu 70 ${ }^{\circ} \mathrm{C}$ menggunakan waterbath. Fase air ditambahkan ke dalam fase minyak dalam keadaan panas-panas, lalu diaduk sampai homogen, keadaan panas ini bertujuan supaya semua bahan tercampur homogen pada masing-masing fase (fase air/fase minyak) untuk menghasilkan Krim yang baik. Setelah masa campuran (fase air dan fase minyak) diaduk dan digerus dalam mortar hingga terbentuk masa krim yang homogen.

\section{Uji Stabilitas VC}

Uji stabilitas krim dilakukan dengan mendiamkan selama 21 hari pada suhu ruang. Pengamatan sifat fisik dilakukan tiap minggu dengan memperhatikan organoleptis, $\mathrm{pH}$, daya Lekat, dan daya sebar sediaan krim.

\section{Uji Organoleptik}

Pada pembuatan 3 formula VC ini, hari ke-1, hari ke-7, dan hari ke-14 dengan masing-masing formula mempunyai konsentrasi yang berbeda. Kontrol kualitas VC dilakukan pada pembuatan hari ke-1 dan sampai dengan penyimpanan hari ke-14. Setelah penyimpanan pada hari ke-14 dam hari ke-21 bentuk dari krim F1, F2, F3 menjadi sangat kental.

Hasil kontrol kualitas VC pada hari ke-1, hari ke-7, hari ke-14, dan hari ke-21 menunjukkan bahwa formula I berwarna hijau kecoklatan dibandingkan dengan formula II dan formula III yang berwarna hijau lumut perbedaan warna yang disebabkan karena kurangnya pengadukan atau kelebihan ekstra yang diberikan, namun ketiga formula tidak mengalami perubahan bau, dan tekstur.

\section{Uji $p H$}

Menurut Tranggono (2007) nilai $\mathrm{pH}$ sediaan harus mendekati nilai $\mathrm{pH}$ kulit yaitu 4,5-6,5. Hasil pengujian $\mathrm{pH}$ pada semua sediaan sangat berbeda, untuk hari ke-1 dan hari ke-7 ketiga formula 
tersebut mendapatkan $\mathrm{pH}$ sebesar 5 tetapi pada hari ke-14 formula I mendapatkan pH sebesar 5 . Setelah penyimpanan pada hari ke-14 pada formula II dan formula III mengalami kenaikan $\mathrm{pH}$ yaitu 6, sedangkan untuk penyimpanan hari ke-21 ketiga formula $V C$ mendapatkan $\mathrm{pH}$ sebesar 6.

Kenaikan $\mathrm{pH}$ tersebut masih melebihi $\mathrm{pH}$ normal kulit. $\mathrm{pH}$ tidak boleh terlalu asam karena dapat mengiritasi kulit dan tidak boleh terlalu basa karena dapat membuat kulit menjadi bersisik. Kenaikan $\mathrm{pH}$ terjadi kemungkinan disebabkan karena pengaruh suhu. Penurunan $\mathrm{pH}$ disebabkan karena pengaruh suhu dan adanya kandungan zat lain dalam sediaan yang ikut bereaksi yang mengganggu (Dureja, 2010, Vasiljevic, 2005).

\section{Uji Homogenitas}

Hasil pengujian homogenitas VC pada hari ke-1, hari ke-7 dan hari ke-14 menunjukkan bahwa krim formula I, formula II, dan formula III homogen. Krim formula I menjadi tidak homogen setelah penyimpanan selama 21 hari ditemukan adanya butiran-butiran kasar. Lachamn et al., (1994) menyatakan bahwa homogenitas sistem emulsi dipengaruhi oleh tekni atau cara pencampuran yang dilakukan.

\section{Uji Daya Sebar}

Hasil pengujian tiga basis formula (tanpa ekstrak) VC, daya sebar pada hari ke-21 memiliki daya sebar yang bagus. Sedangkan untuk formula VC vernonia setelah penyimpanan hari ke-14 dan hari ke-21 ketiga formula memiliki daya sebar yang bagus.

Berdasarkan hasil daya sebar bisa dilihat pada tabel 11 untuk basis formula vanishing cream (tanpa ekstrak) dan formula VC vernonia, mempunyai persyaratan daya sebar untuk sedian topikal yaitu sekitar 5-7 cm. Daya sebar yang baik menyebabkan kontak antara obat dengan kulit menjadi luas, sehingga absorpsi obat ke kulit berlangsung cepat.

Daya sebar yang tidak baik kemungkinan disebabkan karena perbandingan emulgator minyak dan emulgator air tidak seimbang sehingga kekentalannya semakin bekurang. Hal ini juga berkaitan dengan jumlah air yang digunakan dalam pembuatan VC dikurang dengan jumlah ekstrak vernonia yang ditambahkan sehingga basis I, II, dan III kekentalannya berbedabeda.

\section{Uji Daya Lekat}

Pada pengujian tiga formula, daya lekat yang paling bagus adalah penyimpanan pada hari ke 21, Sedangkan pada pengujian daya lekat basis formula yang paling bagus adalah basis formula II. Semakin bertambahnya waktu maka daya lekat semakin lama dikulit sehingga bau vernonia dari $V C$ akan menempel lama dikulit. Krim dikatakan baik jika daya lekatnya itu besar pada tempat yang diobati karena obat tidak mudah lepas sehingga dapat menghasilkan efek yang diinginkan.

\section{KESIMPULAN}

Berdasarkan hasil penelitian dapat disimpulkan bahwa hasil uji fitokimia dari daun afrika ( $V$. amygdalina) menunjukkan adanya kandungan alkaloid, flavonoid, tanin, saponin, steroid, dan triterpenoid. Ekstrak daun afrika dapat dibuat formula basis VC yang telah memenuhi beberapa persyaratan pengujian VC yang baik meliputi uji Organoleptik, uji homogenitas, uji $\mathrm{pH}$, uji daya sebar, uji daya lekat, dan uji keamanan VC dengan membagikan kuisioner. Uji stabilitas krim dilakukan dengan mendiamkan selama 21 hari pada suhu ruang. Pengamatan sifat fisik dilakukan tiap minggu dengan memperhatikan organoleptis, $\mathrm{pH}$, daya lekat, dan daya sebar sediaan krim.

Sediaan granul yang mengandung kombinasi ekstrak kayu secang dan rimpang temu mangga tidak dibuat karena serbuk ekstrak temu mangga tidak mempunyai aktivitas antibakteri. Sediaan granul yang mengandung serbuk ekstrak kayu secang dapat dibuat dengan mutu yang baik.

Sediaan granul telah terpilih formula 1 berdasarkan aktivitas antibakteri sebesar $18,7 \mathrm{~mm}$ terhadap bakteri E. coli, $28,3 \mathrm{~mm}$ terhadap bakteri Salmonella sp., 30,5 mm terhadap bakteri Shigella sp. dan uji kesukaan konsumen. Sediaan granul 
serbuk ekstrak kayu secang telah memenuhi standar mutu granul, kecuali kelembaban.

\section{DAFTAR PUSTAKA}

Adiukwu, P.C., F.I.B. Kayanja, G.K. Nambatya, S. Rugera, J.O.C. Ezeonwumelu, J.K. Tanayen, B.J. Murokore, O. Twikirize, S. Twinomujuni, D. Byamugisha, and L. Imanirampa. 2013. Antipyretic and antinociceptive properties of the aqueous extract and saponin from an edible vegetable: Vernonia amygdalina leaf. African J. Food Agr. Nutrition Dev. 13(2): 1-20.

Afolabi, A.B., A.O. Oyeyemi, T.O. Obafemi, and A.O. Fadaka. 2014. In vitro antimicrobial effects of stem bark extracts of Vernonia amygdalina. J. of Advancement in Medical and Life Sciences. 1(3): 1-3.

Akah, P.A., J.A. Alemji, O.A. Salawu, T.C. Okoye, and N.V. Offiah. 2009. Effects of Vernonia amygdalina on biochemical and hematological parameters in diabetic rats. Asian Journal of Medical Sciences. 1(3): 108-113.

Akah, P., O. Njoku, A. Nwanguma, and D. Akunyuli. 2004. Effects of aqueous leaf extract of vernonia amygdalina on blood glucose and triglyceride levels of alloxaninduced diabetic rats (Rattus rattus). Animal Research International. 1(2): 90 - 94.

Ardhita, E. 2013. Keanekaragaman tumbuhan berguna di hutan lindung Gunung Slamet RPH Baturraden, BKPH Gunung Slamet Barat, KPH Banyumas Timur. Jurusan Konservasi Sumberdaya Hutan Dan Ekowisata, Fakultas Kehutanan IPB. Bogor.

Asawalam, E.F. and A. Hassanali. 2006. Constituents of the essential oil of Vernonia amygdalina as maize weevil protectants. Tropical and Subtropical Agroecosystems. 16: 95-102.

Audu, S.A., A.E. Taiwo, A.R. Ojuolape, A.S. Sani, A.R. Bukola, and I. Mohamed. 2012. A study review of documented phytochemistry of amygdalina (family Asteraceae) as the basis for pharmacologic activity of plant extract. Journal of Natural Sciences Research. 2(7): 1-9.

Atangwho, I.J., G.E. Egbung, M. Ahmad, M.F. Yam, and M.Z. Asmawi. 2013. Antioxidant versus anti-diabetic properties of leaves from $V$. amygdalina. growing in Malaysia. Food Chemistry. 141: 3428-34.

BPOM. 2000. Parameter standar umum ekstrak tumbuhan obat, Departemen Kesehatan RI. Direktorat Jenderal Pengawasan Obat Dan Makanan Direktorat Pengawasan Obat Tradisional. Hal.: 10-12.

Bukar, A.M., M.A. Isa, H.S. Bello, and A.S. Abdullah. 2013. Antibacterial activityof aqueous and ethanolic leaf extracts of vernonia amygdalina on selected species of gram positive and gram negative bacteria. International Journal of Environment. 2(1): 147-151.

Ciulei, J. 1984. Metodology for analysis of vegetables and drugs. Faculty of Pharmacy. Bucharest Rumania. pp: 11-26.
Dureja, H., D. Kaushik, M. Gupta, V. Kumar, V. Lather, and V. 2005. Cosmeceuticals: An emerging concept. Indian J Pharmacol. 37(3): 155-159.

Fransworth, N.R. 1966. Biological and phytochemical screening of plant. J. pharm. Sci. 55(3): 225-265.

Erasto, P., D.S. Grierson, and A.J. Afolayan. 2008. Bioactive sesquiterpene lactones from the leaves of Vernonia amygdalina. Int. J. Environ. Res. Public Health. 5(5): 342-348.

Ibrahim, G., E.M. Abdurahman, H. Ibrahim, and N.O. Ibrahim. 2010. Comparative cytomorphological studies on the studies of $V$. amygdalina Del. and V. kotschyama. Nigerian Journal of Botany. 23(1): 133-142.

Ijeh, I.L., and C.E.C.C. Ejike. 2011. Current perspectives on the medicinal potentials of $V$. amygdalina. Journal of Medicinal Plant Research. 5(7): 1051-1061.

Marliana, S.D., V. Suryanti, dan Suyono. 2005. Skrining fitokimia dan analisis kromatografi lapis tipis komponen kimia buah labu siam (Sechium edule Jacq. Swartz.) dalam ekstrak etanol. Biofarmasi. 3(1): 26-31.

Modu, S., A.E. Adeboye, A. Maisaratu, and B.M. Mubi. 2013. Studies on the administration of $V$. amygdalina. (Bitter leaf) and glucophage on blood glucose level of alloxan Induced diabetic rats. International Journal of Medicinal Plant and Alternative Medicine. 1(1): 13-19.

Momoh, M.A., U. Muhamed, A.A. Agboke, E.I. Akpabio, and E.O. Uduma. 2012. Immunological effect of aqueous extract of Vernonia amygdalina and a known immune booster called immunace ${ }^{\circledR}$ and their admixtures on HIV/AIDS clients: a comparative study. Asian Pacific Journal of Tropical Biomedicine: 181-184.

Nalule, A.S., J.M. Mbaria, and J.W. Kimenju. 2013. In vitro anthelmintic potential of Vernonia amygdalina and Secamone africana on gastrointestinal nematodes. Agriculture and biology journal of north america. Vol 4(1): 54-66.

Omoregie, E.S., A. Pal, and B. Sisodia. 2011. In vitro antimalarial and cytotoxic activities of leaf extracts of Vernonia amygdalina (del.). Nigerian Journal of Basic and Applied Science. 19(1): 121- 126.

Oriakhi, K., E.I. Oikeh, O. Ezeugwu, O. Anoliefo, O. Aguebor, and E.S. Omoregie. 2014. Comparative antioxidant activities of extracts of Vernonia amygdalina and Ocimum gratissimum leaves. Journal of Agricultural Science. 6(1): 1320.

Robinson, T. 1995. Kandungan organik tumbuhan tingkat tinggi. Penerbit ITB. Bandung.

Sharon, N., A. Syariful, dan Yuliet. 2013. Formulasi krim antioksidan ekstrak etanol bawang hutan (Eleutherine palmifolia L. Merr). Universitas Tadulako.

Tranggono, R.I.S., F. Latifah dan J. Djajadisastra. 2007. Buku Pegangan Ilmu Pengetahuan Kosmetik. Jakarta: PT. Gramedia Pustaka Utama.

Vasiljevic, D., G. Vuleta, and M. Primorac. 2005. The characterization of the semi-solid $\mathrm{w} / \mathrm{o} / \mathrm{w}$ emulsions with low concentraions of the primary polymeric emulsifier. Int J Cosmet Sci. 27(2): 81-87. 
Zenebe, M.M., B.K. Dessie, G. Getachew, and W.H. Mariam. 2015. Isolation, structural elucidation, and bioactivity studies of leaf extract of Vernonia Amygdalina. American Journal of Applied Chemistry. 3(1): 14-20. 